7. Reprod. Fert. (1974) 41, 489-492

\title{
THE INHIBITORY ACTION OF PHOSPHATIDYL COMPOUNDS ON BOAR SEMINAL HAEMAGGLUTININ
}

\author{
T. K. ROBERTS* AND J. C. BOURSNELL \\ A.R.C. Unit of Reproductive Physiology and Biochemistry, Cambridge $\dagger$
}

(Received 7th Fune 1974)

Previous publications (Boursnell \& Roberts, 1974; Roberts, Boursnell \& Brown, 1974; Roberts, Boursnell, Winsor \& Mustill, 1974) have shown that the basic boar seminal haemagglutinin (Boursnell \& Briggs, 1969) almost certainly combines with zinc in the seminal plasma (Boursnell, Baronos, Briggs \& Butler, 1972) to produce reversible opalescence on cooling. The relative magnitude of the opalescence at any one temperature resembles the degree of damage observed when the spermatozoa are subjected to cold shock at that temperature. Boar spermatozoa also showed enhanced absorption of zinc protein at $4^{\circ} \mathrm{C}$. Attempts were made to define the nature of the structures binding haemagglutinin. Nelson \& Boursnell (1966) showed that substances of high molecular weight inhibited the haemagglutinin reaction, perhaps non-specifically, and no markedly inhibitory low molecular weight material could be found. Certain red cell species-specificities were, however, noted in some haemagglutinin fractions and Boursnell (1967) reported agglutination of heterologous spermatozoa by the boar seminal haemagglutinin. The present study suggests a new mechanism of haemagglutinin binding to erythrocytes and spermatozoa.

The phenomenon of cold opalescence appeared to offer another way of attacking this problem. A large number of widely differing compounds of low molecular weight were screened by measuring, as described by Boursnell \& Roberts (1974), the opalescence values at room temperature and at $4^{\circ} \mathrm{C}$ (after $16 \mathrm{hr}$ at this temperature) of seminal plasma samples with added $200 \mathrm{~mm}$ neutralized compounds to give 9,5 and $1 \mathrm{~mm}$ final concentrations. These were compared with untreated controls. Four classes of substances showed marked effects; sulphate, which cleared opalescence, and thiol compounds, metabisulphite and phospholipids which increased opalescence markedly.

Because of their known occurrence as integral components of cell membranes, attention was directed towards the phospholipids. Simultaneous haemagglutination inhibition studies demonstrated their importance and specificity.

In tests of the actions of phosphatidyl substances, solutions or suspensions (usually $10 \mathrm{~mm}$ ) were made in buffered saline $(0 \cdot 15 \mathrm{M}-\mathrm{NaCl}$ containing $20 \mathrm{~mm}$ tris, $\mathrm{pH} \mathrm{8).} \mathrm{The} \mathrm{suspensions} \mathrm{in} \mathrm{saline} \mathrm{contained} \mathrm{in} \mathrm{a} \mathrm{small} \mathrm{tube,} \mathrm{were} \mathrm{dis-}$ persed by the use of a Whirlimixer (Fisons, Loughborough, Leics) used with a 2-mm glass bead. Suitable dilutions were quickly made in buffered saline for the

* Present address : Department of Biological Sciences, University of Newcastle, New South Wales 2308, Australia.

$†$ Postal address: Animal Research Station, 307 Huntingdon Road, Cambridge GB3 0JQ. 
opalescence work, conducted with and without added 1 mm-EDTA, and for the haemagglutination tests which were carried out in haemagglutination trays (Stanetray A, Stayne Laboratories, Bishop Auckland, Co. Durham) against 1\% sheep or pig red cells obtained from blood collected in citrated saline by washing in buffered saline. The final pig cell suspensions contained $100 \mathrm{~mm}-\mathrm{MgCl}_{2}$ to minimize haemolysis. Serial doubling dilutions of the testing inhibitor were prepared in buffered saline, $0 \cdot 2-\mathrm{ml}$ dilutions $(1 / 100, \mathrm{v} / \mathrm{v})$ of seminal plasma were quickly added to each well and thoroughly mixed. The trays were kept at room temperature for $2 \mathrm{hr}$; aliquots $(0.2 \mathrm{ml})$ of the appropriate red cell suspension were then added and mixed and the degree of inhibition was recorded after $2 \mathrm{hr}$ at room temperature.

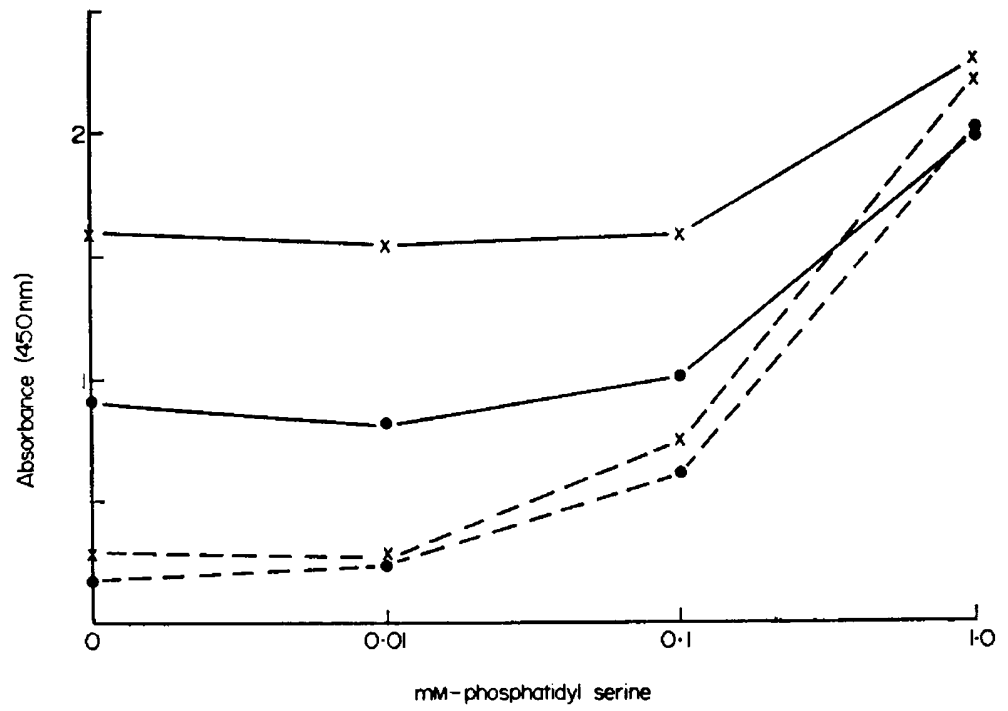

TEXT-FIG. 1. Absorbance values $(\longrightarrow)$ at room temperature $(\bullet)$ and $4^{\circ} \mathrm{C}(x)$ of normal boar seminal plasma samples or of samples treated with phosphatidyl serine in buffered saline to give the final mM concentrations stated. - - , Similar samples containing $1 \mathrm{~mm}$ EDTA, pH 8.

Text-figure 1 records the opalescence resulting from additions to fresh boar seminal plasma $(\mathrm{C}, 8 / 8 / 73)$ of phosphatidyl serine (BDH Chemicals, Poole, Dorset) in the presence and absence of 1 mm-EDTA. Very similar reactions were shown by phosphatidyl choline (lecithin, egg, grade 1: BDH Chemicals), phosphatidyl ethanolamine (egg, grade 1: BDH Chemicals) and phosphatidyl inositide (brain extract, type 1: Sigma London Chemical Co.). The evidence of all four experiments conducted simultaneously on the same seminal plasma sample showed that, at $0.01 \mathrm{~mm}$-phosphatidyl concentrations, there is no significant interference with the opalescence changes caused by cooling or EDTA. At $1 \mathrm{~mm}$ concentrations these changes are almost completely eliminated. The intermediate phosphatidyl concentration of $0.1 \mathrm{~mm}$ only partly interfered with both phenomena. Lysophosphatidyl choline (lysolecithin, egg: BDH Chemicals) behaved differently; at 0.01 and $0.1 \mathrm{~mm}$ concentrations, the increases in opalescence were very small at room temperature and considerably smaller at $4^{\circ} \mathrm{C}$ than with the phosphatidyl compounds. Glycerylphosphoryl 
choline (GPC), even at $5 \mathrm{~mm}$ concentration, produced a minor rise in the opalescence at room temperature and no significant change in the normal seminal plasma increase at $4^{\circ} \mathrm{C}$. Diphosphatidyl glycerol (Cardiolipin, Kochlight Laboratories, Colnbrook, Bucks) at $1 \mathrm{mg} / \mathrm{ml}$ behaved similarly. The results of haemagglutination inhibition experiments which involved doubling dilutions of seminal plasma samples and of inhibitor are shown in Text-fig. 2. These tests revealed that the amount of phosphatidyl compound necessary to

Dilutions of serninal plasmo

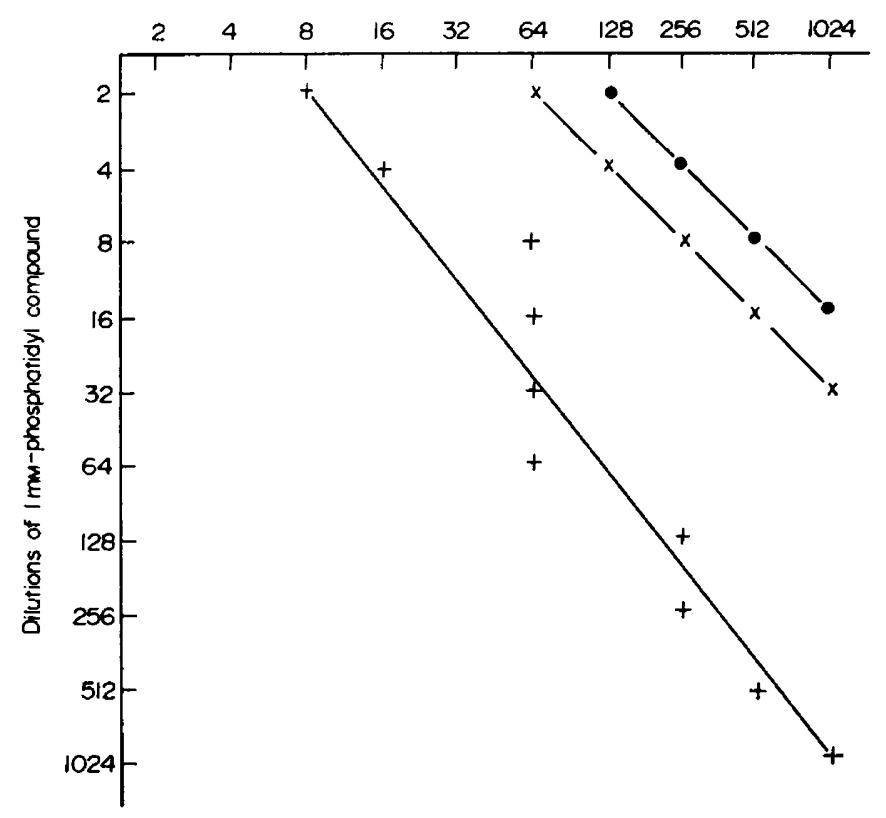

TEXT-FIG. 2. Inhibition of boar seminal haemagglutinin titration against sheep red cells by dilutions of phosphatidyl inositide $(+)$, phosphatidyl serine $(x)$ and phosphatidyl choline ( ). Doubling dilutions in all cases. The symbols represent the last dilution showing haemagglutination.

inhibit haemagglutination by any one seminal plasma was almost exactly proportional to the haemagglutinin titre of that sample of seminal plasma.

Further inhibition tests using $1 / 100$ dilutions of seminal plasma samples with sheep red cells showed minimum inhibitory concentrations as follows: for phosphatidyl-inositide and -serine, $40 \mu \mathrm{M}$; for phosphatidyl-choline and -ethanolamine, $1250 \mu \mathrm{M}$; for cardiolipin, $625 \mu \mathrm{M}$. When pig red cells were used, the potency of phosphatidyl choline was ten times greater than with the other phosphatidyl compounds.

The following substances caused no inhibition at the maximum concentrations stated: GPC, $40 \mathrm{~mm}$; D-glucose, D-mannose, D-fucose, D-galactose, maltose, dextran, cellobiose, orcinol, meso-inositol, $\mathrm{N}$-acetyl glucosamine, glucose-1phosphate, fructose-1,6-diphosphate, $25 \mathrm{~mm}$; D-galactose-2-sulphate, D-galactose-4-sulphate, D-galactose-6-sulphate, $15 \mathrm{~mm}$; Na phytate, DL-O-phosphoserine, elaidic acid, oleic acid, cholesterol, $5 \mathrm{~mm}$. Inhibition was not affected by the bases choline, serine, ethanolamine and inositol. 
The results of this work show that the most probable specific sites for the attachment of boar seminal haemagglutinin on the red cells could be a lipidcontaining structure, possibly occurring as a glycophospholipid or some analagous combination in the membrane matrix and not merely the oligosaccharides sought by Nelson \& Boursnell (1966). The inhibitory potency of the phosphatidyl compounds and their differing specificity to the red blood cell species examined suggest that specificity may also reside in the sperm membranes. Evidence in favour of this view is offered by observations of the agglutination of heterologous spermatozoa by boar seminal plasma (Boursnell, 1967). A characteristic sulphoglycolipid has recently been isolated from boar spermatozoa by Ishizuka, Suzuki \& Yamakawa (1973).

The association of zinc with the basic haemagglutinin and phosphatidyl lipids raises a number of interesting possibilities in connection with the uptake of the haemagglutinin by boar epididymal spermatozoa (Boursnell, 1967), when these are cooled (Roberts, Boursnell \& Brown, 1974). Zinc has also been shown by Westmoreland, First \& Hoekstra (1967) to be additionally absorbed by cooled boar spermatozoa.

There are a number of recent references (see Chvapil, 1973) to the importance of zinc in the maintenance of the stability of membranes. The observations reported in this paper suggest that a specific association of zinc, a basic protein and a membrane lipid structure may contribute to this maintenance. Present evidence also suggests that this association is altered, possibly irreversibly, by cooling; this evidence may be relevant to cryobiological studies. The application of these results to the successful protection of boar spermatozoa against cold-shock will be reported.

We would like to thank Miss S. E. Winsor, Miss W. J. Butler and Mr A. D. Brown for their help and the RGVS Trust Fund for a Senior Fellowship in Animal Health to one of us (T.K.R.).

\section{REFERENGES}

BOURSNELl, J. C. (1967) Boar seminal haemagglutinin. II. Combination with red cells and spermatozoa. 7. Reprod. Fert. 13, 297.

Boursnell, J. G., Baronos, S., Briggs, P. A. \& Butler, E. J. (1972) The concentrations of zinc in boar seminal plasma and vesicular secretion in relation to those of nitrogenous substances, citrate, galactose and fructose. 7. Reprod. Fert. 29, 215.

Boursnell, J. C. \& Briggs, P. A. (1969) Boar seminal plasma proteins. II. Electrophoretic identification of the haemagglutinin. F. Reprod. Fert. 19, 157.

Boursnell, J. C. \& Roberts, T. K. (1974) The rôle of zinc in promoting the opalescence and coldprecipitation of boar seminal plasma. J. Reprod. Fert. 36, 91.

Ghvapil, M. (1973) New aspects in the biological role of zinc: a stabilizer of macromolecules and biological membranes. Life Sci. 13, 1041.

IshizuKa, I., SUzuki, M. \& Y AmaKaWA, T. (1973) Isolation and characterization of a novel sulfoglycolipid, 'seminolipid', from boar testis and spermatozoa. F. Biochem. 73, 77.

Nelson, M. \& Boursnell, J. G. (1966) Studies on boar seminal plasma proteins. 4. Isolation of factors with haemagglutinating and protein-precipitating activity. Biochim. biophys. Acta, 117, 144.

RoBerts, T. K., BOURSNell, J. C. \& BROWN, A. D. (1974) The rôle of zinc in promoting the opalescence and cold precipitation of boar seminal plasma. II. Relationship of a zinc-precipitable protein with the haemagglutinin. 7. Reprod. Fert. 37, 373.

Roberts, T. K., Boursnell, J. G., Winsor, S. E. \& Mustill, E. A. (1974) The rôle of zinc in promoting the opalescence and cold-precipitation of boar seminal plasma. III. Further observations on the nature of the cold-opalescence phenomenon. 7. Reprod. Fert. 40, 411.

Westmoreland, N., First, N. L. \& Hoekstra, W. G. (1967) In-vitro uptake of zinc by boar spermatozoa. F. Reprod. Fert. 13, 223. 